\title{
AGENESIS OF THE POSTERIOR ARCH OF THE ATLAS
}

\author{
Martin Torriani and José Leonardo Goes Lourenço
}

RHCFAP/3072

TORRIANI M. et al. - Agenesis of the posterior arch of the atlas. Rev. Hosp. Clín. Fac. Med. S. Paulo 57(2):73-76, 2002.

PURPOSE: To illustrate the radiological findings and review the current literature concerning a rare congenital abnormality of the posterior arch of the atlas.

CASE REPORT: An adult female without neurological symptoms presented with an absent posterior arch of the atlas, examined with plain films and helical computerized tomography.

Complete agenesis of the posterior arch of the atlas is a rare entity that can be easily identified by means of plain films. Although it is generally asymptomatic, atlantoaxial instability and neurological deficits may occur because of structural instability. Computerized tomography provides a means of assessing the extent of this abnormality and can help evaluate the integrity of neural structures.

Although considered to be rare entities, defects of the posterior arch of the atlas may be discovered as incidental asymptomatic findings in routine cervical radiographs. Familiarity with this abnormality may aid medical professionals in the correct management of these cases.

DESCRIPTORS: Atlas. C1. Abnormalities. Computerized tomography. X-ray.

Structural defects of the posterior arch of the atlas are rare, comprising abnormalities that may present as clefts with variable location and size, ranging to more extensive defects such as complete agenesis. In general, such abnormalities are asymptomatic; however, they may be associated with atlantoaxial instability and neurological deficits ${ }^{1}$.

In this report, we describe a patient with an absent posterior arch of the atlas, as diagnosed with the radiological findings from plain films and computerized tomography $(\mathrm{CT})$.

\section{CASE REPORT}

A 24-year-old white woman presented with nonspecific neck pain and was referred for radiographic examination of the cervical spine. There was no previous history of cervical trauma, and neurological examination was negative. Cervical spine radiographs demonstrated complete absence of the posterior arch of the atlas and a hypertrophic downward projection of the posterior border of the foramen magnum (Fig. 1). There was no evidence of atlantoaxial instability in flexion and extension views. A helical-CT examination with $2.7 \mathrm{~mm}$-thick sections of the cervico-occipital region was performed and confirmed the absence of ossification throughout the posterior

From the Department of Radiology, State University of Campinas, School of Medicine (FCM-UNICAMP). arch of $\mathrm{C} 1$ (Fig. 2). Using appropriate window settings, we found no evidence of involvement of neural structures. A 3-dimensional reconstruction provided an additional perspective of this anomaly (Fig. 3). Magnetic resonance imaging was not performed because of the absence of neurological symptoms.

\section{DISCUSSION}

The posterior arch of the atlas begins its ossification during the seventh week of intrauterine life, proceeding perichondrally from two centers located in the lateral masses. The laminae arise from buds in these chondrification centers and extend dorsally, being nearly fused at birth, except for several millimeters of cartilage. Com- 


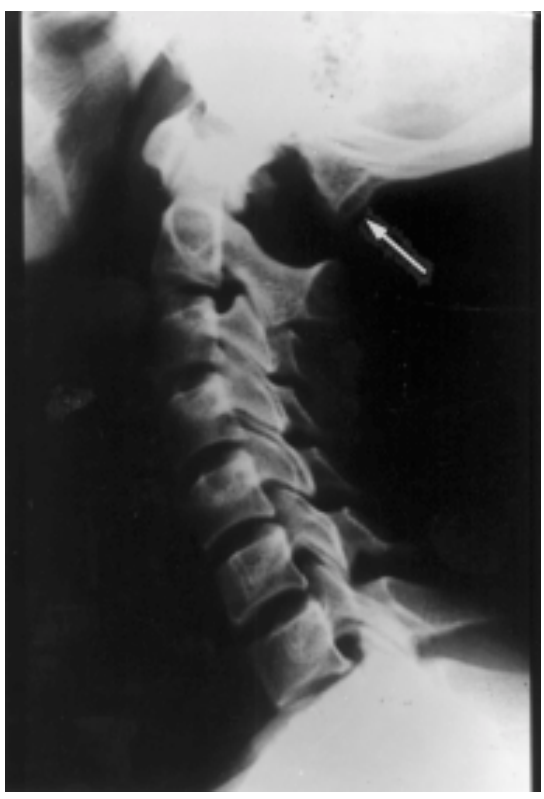

Figure 1 - Lateral view of the cervical spine. Complete absence of the posterior arch of the atlas and a hypertrophic downward projection of the posterior border of the foramen magnum (arrow).

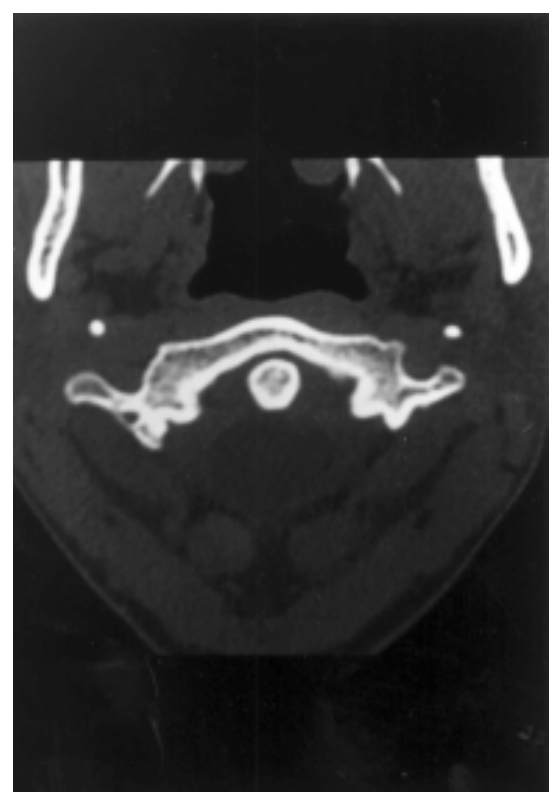

Figure 2 - CT section obtained at the C1 level. The posterior arch of $\mathrm{C} 1$ is missing. The relation between the odontoid and the anterior arch of $\mathrm{C} 1$ is normal.

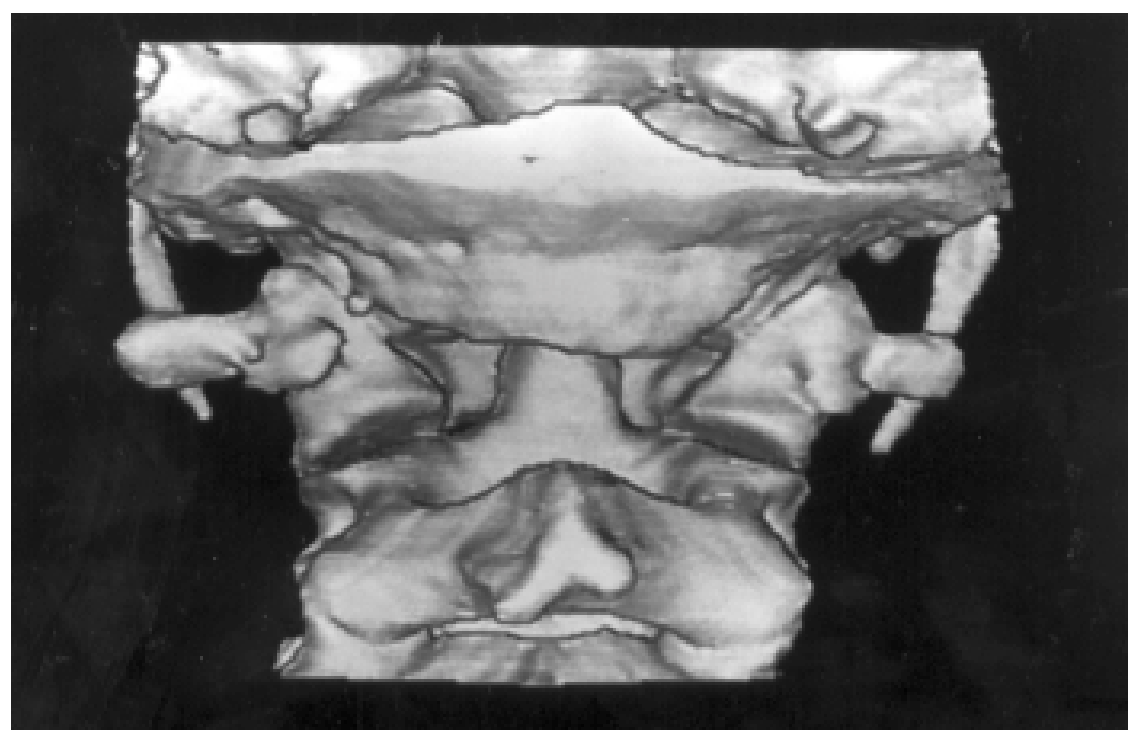

Figure 3 - Three-dimensional rendering of the craniovertebral region, posterior view. The abnormality of $\mathrm{C} 1$ and the craniovertebral region are viewed to best advantage. The abnormality of the foramen magnum partially covers the tip of the odontoid.

plete fusion of the posterior arch is expected to occur between 3 and 5 years of age. In about $2 \%$ of the population, an additional center may be present posteriorly in the midline, forming the posterior tubercle of the atlas during the second year of life ${ }^{1-6}$.

At least two different anomalies can develop during the ossification process: 1) median clefts of the posterior arch of $\mathrm{C} 1$, and 2) varying degrees of posterior arch dysplasia ${ }^{1,5}$. These findings have been further classified as follows: median clefts of the posterior arch of C1 (Type A), unilateral cleft defects (Type B), bilateral cleft defects
(Type C), absence of posterior tubercle (Type D), and total agenesis of the posterior arch (Type E). Type A clefts occur in about $4 \%$ of the population and represent $97 \%$ of all posterior defects. Type B through E defects have been reported to occur in $0.69 \%$ of the population ${ }^{1}$. These disturbances have been attributed to anomalies in the cartilaginous preformation of the posterior arch rather than to disturbances of ossification ${ }^{1,3,5}$. In addition, stenosis at $\mathrm{C} 1$ caused by a hypoplastic but complete posterior arch has been reported as a congenital abnormality ${ }^{1}$ and in association with other chromosomal diseases, such as gonadal dysgenesis and Down and Turner syndromes? ${ }^{7}$. Hypoplasia of the atlas could be caused by a failure in dorsal expansion of the two lateral chondrification centers, resulting in premature fusion and a congenitally narrowed spinal canal ${ }^{1}$.

Total or partial aplasia of the posterior atlas arch is rare ${ }^{2,4,5,8}$. The true incidence is not known, and only a few articles report on this particular malformation ${ }^{3,69,10}$. Absence of ossification of the posterior arch of the atlas is asymptomatic and is generally detected as an incidental finding, although it may cause neck pain ${ }^{2,3}$. Although autopsies and surgical explorations have shown that dense fibrous bands bridge the bony gaps and account for a good stability of the upper cervical spine, this defect can be associated with atlantoaxial instability and neurological deficits $^{1,4}$.

Congenital absence or hypoplasia of the posterior arch of $\mathrm{C} 1$ may be associated with several diseases, such as the Arnold-Chiari malformation, gonadal dysgenesis, Klippel-Feil syndrome, and Turner and Down syndromes $^{2,3}$. In the latter, hypoplasia of the posterior arch of $\mathrm{C} 1$, which may increase the risk of atlantoaxial subluxation, was seen in $26 \%$ of 38 children (aged 2-3 years) ${ }^{7}$. Compensatory hypertrophy of the anterior arch of $\mathrm{C} 1$ 
and of the spinous process of $\mathrm{C} 2$ is usually found ${ }^{3}$; however, it was not observed in our case. On the other hand, we observed a hypertrophic downward projection of the posterior border of the foramen magnum, which has not yet been described (Figs. 1 and 3). Nevertheless, this finding can also be interpreted as a coincidental anatomic variation of this region. Other coexisting abnormalities, including clefts of the anterior arch, atlantoaxial rotatory subluxation, anterior atlantoaxial subluxation, and cervical myelopathy, are reported in the literature ${ }^{1-4,7}$. This anomaly can also simulate basilar invagination, Jefferson's fracture, and occipitalization of the atlas ${ }^{3,8}$.
Although a familial incidence is uncertain, a report describing the same disorder in a mother and daughter indicates an autosomal dominant inheritance ${ }^{3}$. Furthermore, it is suggested that myelopathy associated with hypoplasia of the posterior arch of $\mathrm{C} 1$ may have an ethnic association, since 5 of the few cases reported involved oriental individuals ${ }^{1}$.

Because of its inherent imaging characteristics, CT provides excellent contrast between the nonossified and ossified portions of the posterior arch of the atlas (Fig. 2), which can enable precise determination of the extent of the abnormality. CT scans can be particularly useful for smaller defects. However, in patients with neurological symptoms, we believe magnetic resonance imaging should be performed in order to adequately evaluate the spinal cord and adjacent neural structures.

In cases of atlantoaxial instability, posterior fusion is a common surgical procedure, provided the posterior elements of both vertebrae are intact. If the posterior arch of $\mathrm{C} 1$ is abnormal, posterior fusion involves the occiput and lower spinal segments, limiting the mobility of the upper cervical spine. Reconstruction of $\mathrm{C} 1$ and its fusion with $\mathrm{C} 2$ using calvarial bone grafts in an 8-year-old patient with an absent posterior arch of $\mathrm{C} 1$ and atlantoaxial subluxation has been reported ${ }^{5}$.
TORRIANI M e col. - Agenesia do arco posterior do atlas. Rev. Hosp. Clín. Fac. Med. S. Paulo 57(2):7376, 2002.

OBJETIVO: Descrever os achados radiológicos e revisar a literatura de uma anormalidade congênita rara do arco posterior do atlas.

RELATO DE CASO: Uma paciente adulta sem queixas neurológicas apresentava ausência do arco posterior do atlas, examinada através de radiogra- fias simples e tomografia computadorizada helicoidal.

A agenesia completa do arco posterior do atlas é uma entidade rara que pode ser facilmente identificada através de radiografias simples. Apesar de ser geralmente assintomática, instabilidade atlanto-axial e queixas neurológicas podem ocorrer devido à instabilidade estrutural. A tomografia computadorizada possibilita a avaliação da extensão desta anormalidade e pode auxiliar na análise da integridade de estruturas neurais.
Apesar de serem considerados entidades raras, os defeitos do arco posterior do atlas podem ser achados incidentais em radiografias cervicais de rotina. A familiaridade com esta anormalidade pode auxiliar profissionais da área médica no correto manejo destes pacientes.

DESCRITORES: Atlas. C1. Anormalidades. Tomografia computadorizada. Radiografia. 


\section{REFERENCES}

1. PHAN N, MARRAS C, MIDHA R et al. - Cervical myelopathy caused by hypoplasia of the atlas: two case reports and review of the literature. Neurosurgery 1998;43(3):629-33.

2. DALINKA MK, ROSENBAUM AE \& VAN HOUTEN F - Congenital absence of the posterior arch of the atlas. Radiology 1972; 103(3):581-3.

3. MOTATEANU M, GUDINCHET F, SARRAJ H et al. - Case report 665. Congenital absence of posterior arch of atlas. Skeletal Radiol 1991; 20(3):231-2.

4. THOMPSON GH, LIKAVEC MJ, ARCHIBALD I et al. - Atlantoaxial rotatory subluxation, congenital absence of the posterior arch of the atlas, and cerebral palsy: an unusual triad. J Pediatr Orthop $1985 ; \mathbf{5}(2): 232-5$.

5. DUONG DH \& CHADDUCK WM - Reconstruction of the hypoplastic posterior arch of the atlas with calvarial bone grafts for posterior atlantoaxial fusion: technical report. Neurosurgery 1994; 35(6):1168-70
6. SCHULZE PJ \& BUURMAN R - Absence of the posterior arch of the atlas. AJR Am J Roentgenol 1980; 134(1):178-80.

7. MARTICH V, BEN-AMI T, YOUSEFZADEH DK et al. - Hypoplastic posterior arch of $\mathrm{C}-1$ in children with Down syndrome: a double jeopardy. Radiology 1992; 183(1):125-8.

8. SMOKER WR - Craniovertebral junction: normal anatomy, craniometry, and congenital anomalies. Radiographics 1994; 14(2):255-77.

9. LOGAN WW \& STUARD ID - Absent posterior arch of the atlas. Am J Roentgenol Radium Ther Nucl Med 1973; 118(2):431-4.

10. CURRARINO G, ROLLINS N \& DIEHL JT - Congenital defects of the posterior arch of the atlas: a report of seven cases including an affected mother and son. AJNR Am J Neuroradiol 1994; 15(2):249-54

Received for publication on March 20, 2001 